Sains Malaysiana 49(3)(2020): 553-560

http://dx.doi.org/10.17576/jsm-2020-4903-10

\title{
Extending Post-Harvest Quality of Fresh Fig (Ficus carica L.) Fruit Through Manipulation of Pre- and Post-Harvest Practices: A Review
}

(Memanjangkan Kualiti Pasca-tuai Buah Tin (Ficus carica L.) Segar dengan Memanipulasikan Amalan Pra-tuai dan Pasca Tuai: Suatu Tinjauan)

\author{
Nur Athirah Mat Jusoh, Phebe Ding* \& Choon Sea Yeat
}

\section{ABSTRACT}

Fresh fig fruit has a very unique taste. However, it is well-known as very perishable climacteric fruit. The various factors that involve during the pre-harvest and post-harvest handling processes have caused great challenges to farmer in maintaining the keeping quality of fresh fruits. The key factors involve are disease, water supply, fertilizer management, fruit maturity at harvest as well as post-harvest handling. Thus, good pre-and post-harvest practices are very important in improving the storage quality of fresh fig fruit. In this article, the studies on improving the storage life of fig fruit including the practices used during pre-and post-harvest handling of fig fruit were reviewed. For pre-harvest practices, deficit irrigation, application of plant growth regulator (1-methylcyclopropene) and pollination were applied to improve the quality of fresh fig fruit. For post-harvest treatments, coating, modified atmosphere packaging and optimizing the storage temperature and relative humidity were used in keeping the post-harvest quality of fresh fig fruit.

Keywords: Coating; deficit irrigation; storage temperature

\section{ABSTRAK}

Buah tin segar mempunyai rasa yang sangat unik. Namun, ia juga dikenali sebagai buah klimakterik yang cepat rosak. Faktor yang terlibat dalam proses pengendalian pra-dan pasca-tuai telah memberikan cabaran yang hebat kepada pengusaha dalam menjaga kualiti buah segar sepanjang tempoh penyimpanan. Antara faktor yang terlibat termasuk penyakit, bekalan air, pengurusan pembajaan, kematangan buah ketika penuaian dan juga proses pengendalian pascatuai. Oleh itu, amalan pra-dan pasca-tuai yang baik adalah penting dalam meningkatkan kualiti penyimpanan buah tin segar. Kertas ini mengulas kajian terhadap amalan yang dilakukan pada pra- dan pasca-tuai dalam meningkatkan jangka hayat simpanan buah tin. Pada peringkat pra-tuai, amalan ladang seperti pengairan defisit, aplikasi pengawalatur tumbesaran tumbuhan (1-metilsiklopropana) dan pendebungaan sering dijalankan. Bagi amalan pasca tuai, penyalutan, pembungkusan ubah suai atmosfera dan pengoptimaan suhu penyimpanan dan kelembapan relatif merupakan kaedah yang biasa digunakan dalam mengekalkan kualiti pasca-tuai buah tin segar.

Kata kunci: Pengairan defisit; salutan; suhu penyimpanan

\section{INTRODUCTION}

Ficus carica L. or also known as fig which comes from the family Moraceae is believed as one of the oldest fruit tree that cultivated in the world (Solomon et al. 2006). This plant is grown well under typical hot dry summer and mild winter. California, United States is the biggest producer of edible Ficus carica followed by the others countries such as Turkey, Egypt, Morocco, Spain, Greece, Italy, and Brazil (Kader 2002; King et al. 2012; Mawa et al. 2013). The world production of figs in 2017 was 1.15 million tonnes (Food and Agriculture Organization of United Nations 2018). In general, there are four types of fig cultivars: Caprifig or also known as 'male fig' (not edible and is used for its pollen); Smyrna (the edible fig that needs caprification to bear its main crops); San-Pedro (the edible fig that use breba crops to pollinate main crops) and common female type fig (produces crop one or two times per year without caprification) (Flaishman et al. 2008; Galil \& Eisikowitch 1968; Galil \& Neeman 1977).

There are more than 100 types of fig varieties have been cultivated around the world. Among these cultivars, Mission, Brown Turkey and Kadota are the main commercial fig cultivars cultivated in California (Stover et al. 2007). Fig fruit can be consumed fresh or dried. For fresh consumption, it can be eaten either peeled or not (Veberic et al. 2008). In food industry, fig fruit have developed into wide range of processed food products such as jam, tea, wine, powder, canned food, paste and also bakery product such as pastries (Gözlekçi 2010).

Consumption of super fruit has become a trend nowadays especially to those who conscientious about their health. Fresh fig fruit is one of exotic super fruit which is highly consumed besides pomegranate, lychee, papaya and pink guava (Alireza 2010; Bhide 2011). However, keeping the good quality for fresh fig fruit requiring much 
effort. Very often the qualities of fig fruit are evaluated based on the changing of its firmness, colour advancement, decay development and skin cracking during storage (Flaishman et al. 2008).

Ethylene acts in enhancing the maturity and ripening of fig fruit (Crane et al. 1970; Marei \& Crane 1971). Flaishman et al. (2008) stated that fig fruit exhibits climacteric pattern of respiration with moderate ethylene production. Additionally, fig fruit has thin peels that cause skin crack easily. The crack of skin will lead to loss of nutritional values and also expose to the microbial contamination which causes secondary infection (Irfan et al. 2013). These are some of the factors that reduce the fresh fig fruit quality. However, the quality of fruit is not only affected by post-harvest factors. Pre-harvest factor especially water management, plant growth regulator application and pollination technique could also be used to improve post-harvest quality of fruit. As such a review on extending shelf life of fig fruit from the aspect of preand post-harvest was carried out. In terms of economic impact and food safety, the preservation of fresh products is very significant in horticulture industry.

\section{PRE-HARVEST ASPECT}

\section{DEFICIT IRRIGATION}

One of the quality criteria used in fresh fig fruit is the perfectness of fruit without skin cracking and ostiole-end splitting. Ostiole-end is the small opening of synconium (edible part of fig fruit) that surrounded by scales (Figure 1). The ostiole-end were functioned during pollination of fig fruit (Verkerke 1989). However, skin cracking and ostiole-end splitting (Figure 2) will provide the entry sites of fungal decay and loss of moisture in fig fruit which reduce the storage life of fruit (Crisosto et al. 2011; Opara et al. 1997). This kind of fruit disorder is due to high availability of soil water (Shackel et al. 1997). Condit (1947) and Melgarejo (1996) speculated that changes in water status have caused fig cracking and splitting. Water in plant and soil plays a very important role in chemical process and also maintenance of turgidity of plant (Kramer $\&$ Boyer 1995). Water deficit can influence the quality of fruit and the concentration of fruit constituents (Shackel et al. 1997). The excess of water in plant during development and ripening may lead to fruit splitting, while water excess in soil could cause fruit enlargement and watery which eventually cause fruit to rot (Flaishman et al. 2008; Melgarejo 1996). Thus, water supply is very important during the cultivation of fig. In the study of Kong et al. (2013), deficit irrigation was used to reduce the fig fruit side cracking and ostiole-end splitting. Fig fruit skin damaged on cultivar Brown Turkey and Sierra were reduced by using the treatment of regular deficit irrigation (RDI) (Kong et al. 2013). RDI is strategy of irrigation which reducing amount of irrigation during certain plant cycle phases (Chalmers et al. 1981). The imbalanced of water flux from fruit leads to increase internal pressure and maximal elastic limit which caused skin crack of fruit (Gibert et al. 2007; Ohta et al. 1997; Opara et al. 1997). RDI with 55\% crop evatranspiration were applied towards $25 \%$ ripened fig fruits (cv. Brown Turkey and cv. Sierra). Results shows that the skin damaged of fig fruits have reduced and also increased the percentage of sound fruit in cv. Brown Turkey and cv. Sierra. Besides, the treatment also does not give any negative effect to the other quality attributes such as soluble solids concentration, titratable acidity and fruit firmness of fig fruit (Kong et al. 2013).

\section{1-METHYLCYCLOPROPENE}

The 1-methylcyclopropene (1-MCP) is one of the synthetic plant growth regulators. It has similar structural formula $\left(\mathrm{C}_{4} \mathrm{H}_{6}\right)$ with ethylene $\left(\mathrm{C}_{2} \mathrm{H}_{4}\right)$ that prevents the ethylene dependent process by competing with ethylene to bind with ethylene receptors (Guan et al. 2015). Thus, delaying in ripening process. It's very famous as inhibitor of ethylene that produced in harvested fruits, vegetables and floriculture crops (Blankenship \& Dole 2003; Sisler \& Blankenship 1996). In general, post-harvest treatment using 1-MCP have gave positive effects towards postharvest fig fruit quality. It slowed down the softening of fig fruit (Ficus carica cv. Albacor, cv. Bardakci and cv. Brown Turkey) as reported by Gözlekçi et al. (2005), Sozzi et al. (2005), and Villalobos et al. (2016a). Freiman et al. (2012) for the first time published the effects of the 1-MCP application during pre-harvest stage of fig fruit. In the study, fig fruit of cv. Brown Turkey were treated with 5 ppm of 1-MCP on tree after the onset of chlorophyll loss. The result showed that fig fruit that treated with 1-MCP experienced a delay in senescence process. The changes of the treated fig fruit delayed as compared to control fig fruit. Weight loss and size of control fig fruit during storage were reduced more that treated fig fruit. The treated fig fruits were firmer than control fig fruit. The control fig fruits have slightly overripe texture, while treated fig fruits were approached full ripeness. As compared to 1-MCP treated fig fruit, soluble solids concentration in control fig fruit were increased during storage. The 1-MCP also retained the fruit quality as untreated fig fruit gave severe shriveling as compared to the treated fig fruit after 12 days of storage (Figure 3). Fig fruit that treated with 1-MCP during pre-harvest showed improved quality during storage and transportation (Freiman et al. 2012).

\section{POLLINATION}

Assisted pollination has been widely used in fruit industry to obtain good quality of produce. In fig, Rosianski et al. (2016) had conducted a study by hand-pollinating the common fig type with caprifig's pollen to improve the fruit quality. The caprified fig was selected because it has less fruit splitting problem and also produced bigger size of fruit (Condit 1947; Gaaliche et al. 2011). Pollen solution that was collected from caprifig (male-type) were injected 


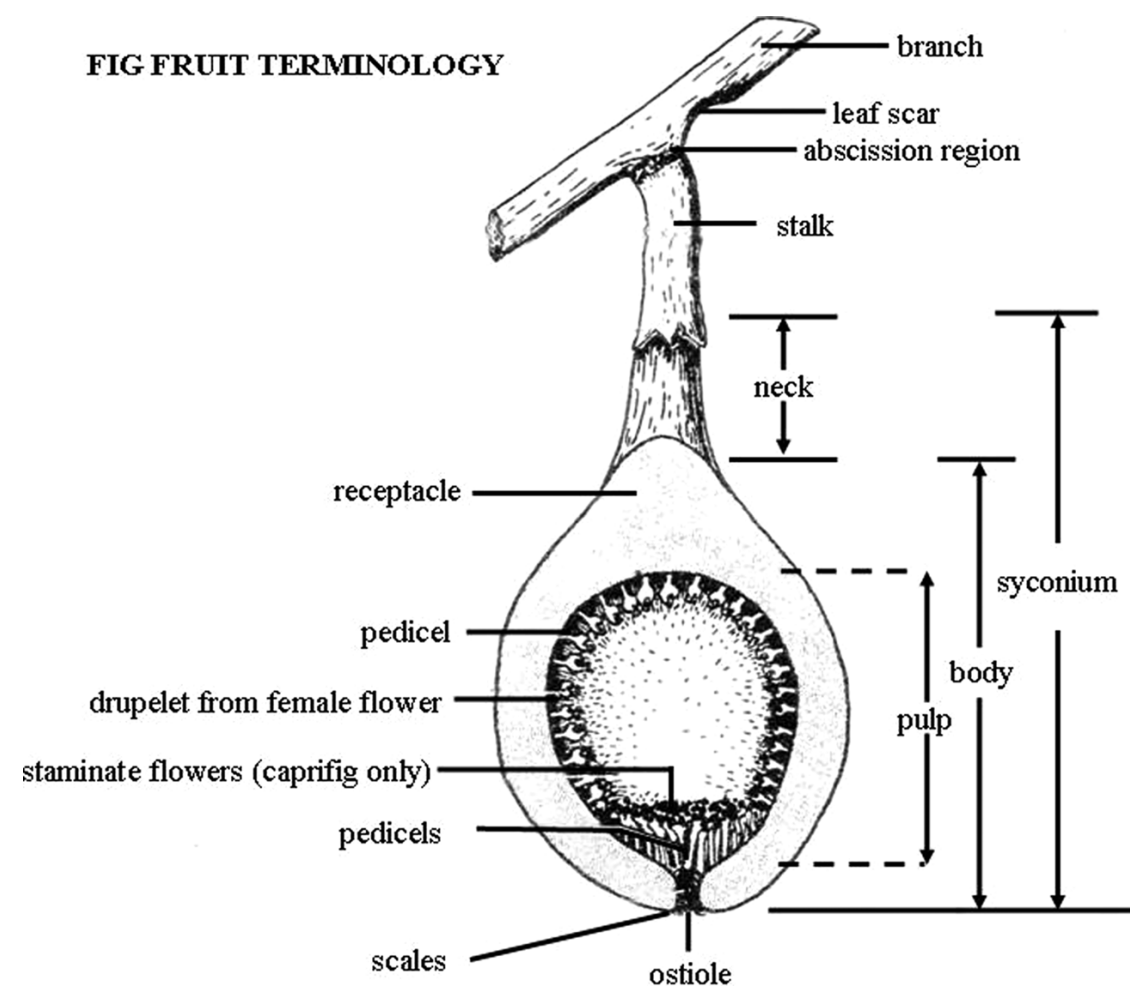

FIGURE 1. Fruit terminology for fig synconium (Source: Flaishman et al. 2008)
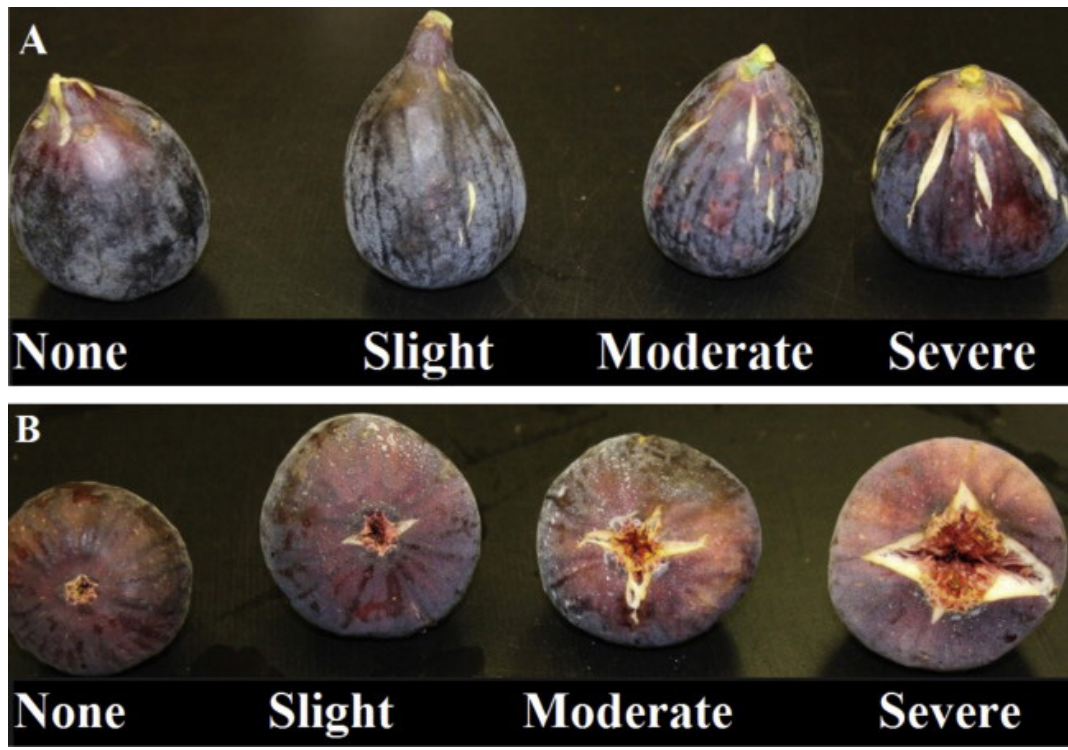

FIGURE 2. Skin damaged of fig fruit (A) Skin cracking and (B) Ostiole-end splitting (Source: Kong et al. 2013)

using plastic syringe (Rosianski et al. 2016). The result showed that the pollinated common fig fruit retained its texture, taste and appearance after 14 days of storage whereby the control, parthenocarpic (fruit set or matured without seed development and without fertilization) fig fruit, has deteriorated (Figure 4) (Pallardy 2010; Rosianski et al. 2016). This result was due to pollinated common fig fruit has thicker cell wall than parthenocarpic fig fruit. The thick fruit cell wall has reduced the loss of cellular water and delayed softening in pollinated fruit during storage (Rosianski et al. 2016). This experiment has also strengthened the results of Condit (1947) and Gaaliche et al. (2011) which reported that pollinated common fig fruit have better quality in texture, size, shape, taste and appearance than parthenocarpic fig fruit during fruit development and ripening. 

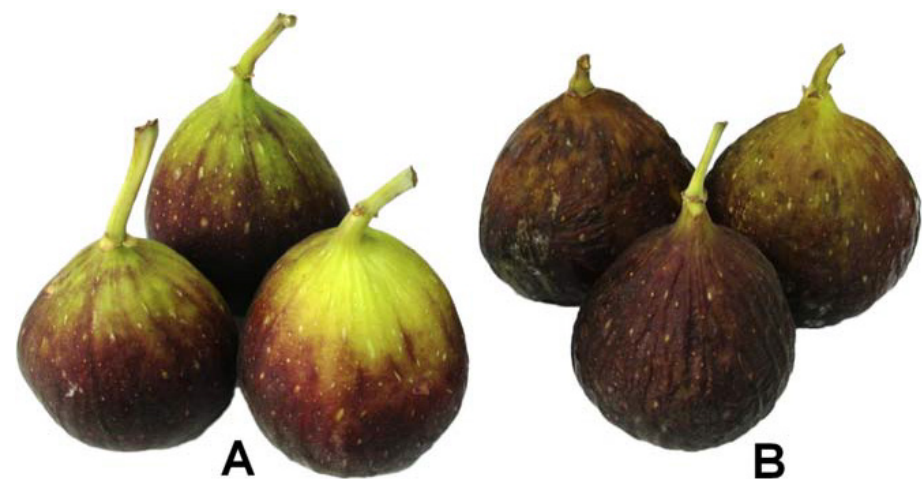

FIGURE 3. Fig fruits appearances that harvested at commercial stage after 12 days of storage and 2 days of shelf life (A) Treated with 1-MCP before harvest, and (B) Control

(Source: Freiman et al. 2012)

A

Pollinated
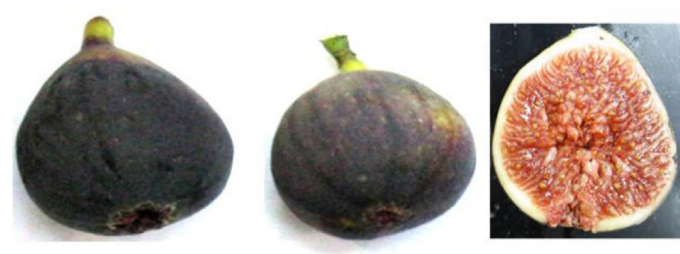

B

Parthenocarpic

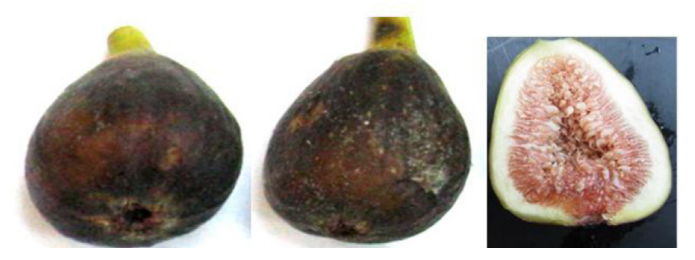

FIGURE 4. Fig fruit $60 \%$ ripened condition after 14 days of storage at $1{ }^{\circ} \mathrm{C}$, (A) Pollinated common fig fruit, and (B) Parthenocarpic fig fruit (Source: Rosianski et al. 2016)

\section{POSTHARVEST ASPECT}

\section{COATING}

The highly perishable fig fruit cannot be stored for long periods of time. One of the methods in extending the shelf life of fresh fig fruit is by using coating which it can thicken and harden the fruit skin without losing its nutritional contents (Irfan et al. 2013). Coating provides the barrier to moisture, oxygen and solute movement which reduce the metabolic processes and water loss (Shahidah \& Ding 2020). The coating materials used must be edible and at the same time it can function in retarding the ripening, prevent enzymatic browning or hold the fresh flavor and aroma of fruits (Nisperos-Carriedo et al. 1991).

Calcium chloride is one of the coating materials that can be used as post-harvest treatment of fresh fruits and vegetables. This is because it can strengthen the cell wall of fruit and make it less accessible to the pectin degrading enzymes such as polygalacturonase, pectate lyase, pectin methyl esterase and rhamnogalacturonase that cause fruit softening and also pathogen that leads to softening, decaying besides reducing the pathogen germination (Conway \& Sams 1984; Conway et al. 1994; Payasi et al. 2009; Sams et al. 1993). The results from the study of Irfan et al. (2013) indicated that fig fruit that treated with $4 \%$ of calcium chloride showed positive effect on fruit quality. The fruit texture, fruit color, titratable acidity, ascorbic acid content were maintained as initial quality and low of soluble solids concentration for 14 days of storage. The untreated control fig fruit that stored under same conditions only recorded 7 days of storage life.

Villalobos et al. $(2017,2016 \mathrm{~b})$ reported that the phenolic compound extracted from soybean meal can be used as coating materials to treat fig fruit (Table 1) as it can reduce pathogen attack that causes fruit spoilage. Soybean meal contains high isoflavones and phenolic compounds that act antioxidant and shows antifungal activity (Wang \& Murphy 1994). The results from the studies of Villalobos et al. $(2017,2016 b)$ showed that the soybean aqueous extract coating allowed fig fruits to be stored in cold storage $\left(0{ }^{\circ} \mathrm{C}\right)$ up to 14 days. 
TABLE 1. Previous studies on soybean meal as coating material of fig fruit

\begin{tabular}{|c|c|c|c|c|}
\hline $\begin{array}{l}\text { Extraction of phenolic } \\
\text { compound procedure }\end{array}$ & $\begin{array}{c}\text { Amount of total } \\
\text { phenolic concentration } \\
\text { used in coating }\end{array}$ & Storage condition & Quality analysis & References \\
\hline $\begin{array}{l}500 \mathrm{~g} \text { defatted soybean meal } \\
\text { mixed with } 80 \% \text { of ethanol } \\
\text { at room temperature before } \\
\text { filtered and concentrated using } \\
\text { rotary evaporator at } 37^{\circ} \mathrm{C}\end{array}$ & 1000 ppm & $\begin{array}{l}\text { Fig fruit dipped in } \\
\text { coating and dried at } 7 \\
{ }^{\circ} \mathrm{C} \text { before packed in } \\
\text { polyethylene punnet and } \\
\text { stored at } 0{ }^{\circ} \mathrm{C} \text { and } 90- \\
95 \% \text { RH in darkness }\end{array}$ & $\begin{array}{l}\text { Gas composition, } \\
\text { physicochemical, } \\
\text { microbial counts, } \\
\text { disorder, weight } \\
\text { loss, texture, sensory } \\
\text { analysis }\end{array}$ & $\begin{array}{c}\text { Villalobos et al. } \\
\text { (2016b) }\end{array}$ \\
\hline $\begin{array}{l}5 \mathrm{~g} \text { of soybean flour extracted } \\
\text { with } 30 \mathrm{~mL} \text { ethanol-water- } \\
\text { hydrochloric acid }(80: 19: 1 \mathrm{v} / \mathrm{v}) \\
\text { before filtered and concentrated } \\
\text { by using rotary evaporator }\end{array}$ & $0.859 \mathrm{mg} \mathrm{GAE} / \mathrm{g}$ & $\begin{array}{l}\text { Fig fruit dipped in } \\
\text { coating and dried at } 7 \\
{ }^{\circ} \mathrm{C} \text { before packed in } \\
\text { polypropylene punnet } \\
\text { and stored at } 0{ }^{\circ} \mathrm{C} \text { and } \\
90-95 \% \mathrm{RH} \text { in darkness }\end{array}$ & $\begin{array}{l}\text { Gas composition, } \\
\text { physicochemical, } \\
\text { microbial counts, } \\
\text { bacterial identification, } \\
\text { fungi identification }\end{array}$ & $\begin{array}{c}\text { Villalobos et al. } \\
\text { (2017) }\end{array}$ \\
\hline
\end{tabular}

TABLE 2. Previous studies on fig fruit cultivar in different conditions of MAP

\begin{tabular}{|c|c|c|c|c|}
\hline Cultivar & MAP & Analysis & $\begin{array}{l}\text { Fig fruit shelf } \\
\text { life (Days) }\end{array}$ & References \\
\hline Bursa Siyahi & $\begin{array}{l}\text { Mono polypropene (PP) sealed } \\
\text { with } 35 \mu \mathrm{m} \text { biaxially oriented } \\
\text { polypropylene (BOPP) + air } \\
\text { Stored at } 4{ }^{\circ} \mathrm{C}\end{array}$ & $\begin{array}{l}\text { Colour, texture, weight loss, } \\
\text { chemical analysis (pH, titratable } \\
\text { acidity, soluble solids concentration), } \\
\text { sensory evaluation }\end{array}$ & 15 & $\begin{array}{c}\text { Ayhan \& Karacay } \\
\text { (2011) }\end{array}$ \\
\hline Bursa Siyahi & $\begin{array}{l}\text { Mono PP sealed with } 35 \mu \mathrm{m} \text { thick } \\
\mathrm{BOPP}+10 \% \mathrm{O}_{2}+20 \% \mathrm{CO}_{2}+70 \\
\% \mathrm{~N}_{2} \\
\text { Stored at } 4{ }^{\circ} \mathrm{C}\end{array}$ & $\begin{array}{l}\text { Colour, texture, weight loss, } \\
\text { chemical analysis (pH, titratable } \\
\text { acidity, soluble solids concentration), } \\
\text { sensory evaluation }\end{array}$ & 15 & $\begin{array}{c}\text { Ayhan \& Karacay } \\
\text { (2011) }\end{array}$ \\
\hline $\begin{array}{l}\text { Brown } \\
\text { Turkey }\end{array}$ & $\begin{array}{l}\text { Polyethylene MAP } \\
\text { Stored at } 2{ }^{\circ} \mathrm{C}\end{array}$ & $\begin{array}{l}\text { Texture, weight loss, soluble } \\
\text { solids concentration, } \mathrm{pH}, \mathrm{CO}_{2} \text { and } \\
\mathrm{C}_{2} \mathrm{H}_{4} \text { concentration, other volatile } \\
\text { compounds }\end{array}$ & 21 & $\begin{array}{l}\text { Bouzo et al. } \\
\text { (2012) }\end{array}$ \\
\hline San Antonio & $\begin{array}{l}\text { Polyethylene punnets sealed with } \\
\text { micro perforated } 40 \mu \mathrm{m} \text { thick BOPP } \\
\text { with one hole per } 50 \mathrm{~mm} \text { (a total of } \\
\text { three holes, } \varnothing=100 \mu \mathrm{m}) \\
\text { Stored at } 0{ }^{\circ} \mathrm{C} \text { and } 90-95 \% \mathrm{RH} \text { in } \\
\text { darkness }\end{array}$ & $\begin{array}{l}\text { Texture, weight loss and disorders, } \\
\mathrm{CO}_{2} \text { and } \mathrm{O}_{2} \text { concentrations, microbial } \\
\text { counts, } \mathrm{pH} \text {, titratable acidity, soluble } \\
\text { solids concentration, sensory } \\
\text { evaluation }\end{array}$ & 14 & $\begin{array}{l}\text { Villalobos et al. } \\
\qquad(2014)\end{array}$ \\
\hline Banane & $\begin{array}{l}\text { Polyethylene punnets sealed with } \\
\text { micro perforated } 40 \mu \mathrm{m} \text { thick BOPP } \\
\text { with one hole per } 50 \mathrm{~mm} \text { (a total of } \\
\text { three holes, } \varnothing=100 \mu \mathrm{m}) \\
\text { Stored at } 0{ }^{\circ} \mathrm{C} \text { and } 90-95 \% \mathrm{RH} \text { in } \\
\text { darkness }\end{array}$ & $\begin{array}{l}\text { Texture, weight loss and disorders, } \\
\mathrm{CO}_{2} \text { and } \mathrm{O}_{2} \text { concentrations, microbial } \\
\text { counts, } \mathrm{pH} \text {, titratable acidity, soluble } \\
\text { solids concentration, sensory } \\
\text { evaluation }\end{array}$ & 21 & $\begin{array}{l}\text { Villalobos et al. } \\
\qquad(2014)\end{array}$ \\
\hline
\end{tabular}

Aloe vera gel is mainly composed of polysaccharides, soluble sugars, proteins, vitamins and minerals. It is capable in maintaining the quality of fresh fruits such as cherry, peach, plum, and nectarine besides extending these fruits shelf life by preserving the physico-chemical qualities such as colour, firmness, total acidity, and reduced respiration rates, ethylene production (for climacteric fruit) and weight loss (Eshun \& He 2004; Paladines et al. 2014). Marpudi et al. (2013) published the first study on effects of Aloe vera gel on fresh fig fruit. Fig fruits were dipped in prepared Aloe vera gel (fresh Aloe vera were mixed with 1.9-2.0 g/L ascorbic acid, 4.5-4.6 g/L citric acid and 1\% commercial gelling agent) and stored at room temperature $\left(29 \pm 3^{\circ} \mathrm{C}\right)$. Parameters such as titratable acidity, soluble solids concentration and weight loss were measured. The result of the study showed that Aloe vera gel was effective in delaying the ripening and decay of fig fruit.

\section{MODIFIED ATMOSPHERE PACKAGING}

Modified atmosphere packaging (MAP) is one of the methods used to extend the shelf life of fresh fruits and vegetables by modifying the oxygen $\left(\mathrm{O}_{2}\right)$ and carbon dioxide $\left(\mathrm{CO}_{2}\right)$ levels within the polymeric film packing 
atmosphere (Mir \& Beaudry 2004). Depending on the thickness of film, chemical composition, density and presence of additives, the different types of films have different degree of permeability to $\mathrm{O}_{2}$ and $\mathrm{CO}_{2}$ (Thompson 2010). The desirable levels of $\mathrm{O}_{2}$ and $\mathrm{CO}_{2}$ influence the product's metabolism that packaged or the activity of organisms which can increase the shelf life of products by preserving firmness and reducing decay, respiration and ethylene production of fruit (Mir \& Beaudry 2004; Thompson 2010).

\section{TEMPERATURE AND RELATIVE HUMIDITY}

Low temperature storage has been used for centuries to extend the shelf life of fruits and vegetables and at the same time, it also protecting quality of commodities; texture, nutrition, aroma and flavor (Paull 1999). Low temperature retains the decaying process while the optimum relative humidity $(\mathrm{RH})$ reduces the water transpiration of fresh fruits and vegetables that leads to less weight loss of fresh produce (Kader 1986). As fig fruit is perishable, storage temperature is one of the important factors in prolonging its storage life (Hernández Méndez et al. 2001a). The process of metabolism in fruits, vegetables and ornamental are influenced by temperature and lowering the temperature will reduce the deterioration of produces (Wills et al. 2007). Rate of enzyme-catalyzed reactions are affected by reduction of metabolism process (Teixeira \& Ferreira 2003). Storage temperature and RH are dependent (Paull 1999). The different cultivars and varieties of figs responded differently to optimum storage temperature and RH. The study of Hernández Méndez et al. (2001b) showed that fig fruit cv. Cuello de dama can be stored for 7 - 10 days at $6{ }^{\circ} \mathrm{C}$ with film wrapping.

In fig fruit var. Ipoh Blue Giant, fruit showed better post-harvest performance in appearance at $5{ }^{\circ} \mathrm{C}$ of storage temperature after 5 weeks of storage than 10 and $15^{\circ} \mathrm{C}$ (Jusoh et al. 2019). In general, fig fruit can be stored at 0 - $6{ }^{\circ} \mathrm{C}$ with 90 - $95 \% \mathrm{RH}$ and the storage life can last for more than 10 days (Ayhan \& Karacay 2011; Hernández Méndez et al. 2001b; Irfan et al. 2013; Villalobos et al. 2014).

\section{CONCLUSION}

This review has demonstrated through manipulation of pre- and post-harvest practices, storage life of fresh fig fruit can be extended. On top of this, understanding the fig fruit characters from morphology and physiology aspects is essential in retaining the quality and prolonging postharvest life of this fruit. Factors such as variety and cultural practices can affect the characteristics of fruits especially during storage life. Thus, selection of suitable variety and cultural practices is very important also in raising healthy plants and eventually good quality fruit being produced. Good quality fruit is the basis in extending fig fruit postharvest life during storage.

\section{ACKNOWLEDGEMENTS}

The authors would like to acknowledge Putra Grant (GPB) given by Universiti Putra Malaysia (UPM/800$3 / 3 / 1 / 9629600$ ) for funding this project.

\section{REFERENCES}

Alireza, M. 2010. The fig: The powerful superfruit. Arab News. http://www.arabnews.com/.

Ayhan, Z. \& Karacay, E. 2011. Preservation of the 'Bursa Siyahı' fresh fig under modified atmosphere packaging (MAP) and cold storage. International Journal of AgriScience 1(1): 1-9.

Bhide, M. 2011. 5 Superfruits You Should Be Eating. https:// www.prevention.com/.

Blankenship, S.M. \& Dole, J.M. 2003. 1-Methylcyclopropene: A review. Postharvest Biology and Technology 28(1): 1-25.

Bouzo, C.A., Travadelo, M. \& Gariglio, N.F. 2012. Effect of different packaging materials on postharvest quality of fresh fig fruit. International Journal of Agriculture and Biology 14(5): 821-825.

Chalmers, D.J., Mitchell, P.D. \& van Heek, L. 1981. Control of peach tree growth and productivity by regulated water supply, tree density, and summer pruning. Journal of American Society of Horticultural Science 106: 307-312.

Condit, I.J. 1947. The Fig. Waltham, Masschusetts: Chronica Botanica $\mathrm{Co}$

Conway, W.S. \& Sams, C.E. 1984. Possible mechanisms by which postharvest calcium treatment reduces decay in apples. Phytopathology 74(2): 208-210.

Conway, W.S., Sams, C.E., Wang, C.Y. \& Abbott, J.A. 1994. Additive effects of postharvest calcium and heat treatment on reducing decay and maintaining quality in apples. Journal of the American Society for Horticultural Science 119(1): 49-53.

Crane, J.C., Marei, N. \& Nelson, M.M. 1970. Growth and maturation of fig fruits stimulated by 2-chloroethylphosphonic acid. Journal of the American Society of Horticultural Science 95: 367-370.

Crisosto, C.H., Bremer, V. \& Stover, E. 2011. Fig (Ficus carica L.). In Postharvest Biology and Technology of Tropical and Subtropical Fruits Vol 3: Cocona to Mango, edited by Kazuz, Y. \& Elhadi, Cambridge: Woodhead Publishing Ltd. pp. 134-158.

Eshun, K. \& He, Q. 2004. Aloe vera: A valuable ingredient for the food, pharmaceutical and cosmetic industries - A review. Critical Reviews in Food Science and Nutrition 44(2): 91-96.

Flaishman, M., Rodov, V. \& Stover, E. 2008. The fig: Botany, horticulture, and breeding. Horticultural Reviews 34: 113196.

Food and Agriculture Organization of United Nations. 2018. http://www.fao.org/faostat/en/\#data/QC.

Freiman, Z.E., Rodov, V., Yablovitz, Z., Horev, B. \& Flaishman, M.A. 2012. Preharvest application of 1-methylcyclopropene inhibits ripening and improves keeping quality of 'Brown Turkey' figs (Ficus carica L.). Scientia Horticulturae 138: 266-272.

Gaaliche, B., Trad, M. \& Mars, M. 2011. Effect of pollination intensity, frequency and pollen source on fig (Ficus carica L.) productivity and fruit quality. Scientia Horticulturae 130(4): 737-742.

Galil, J. \& Eisikowitch, D. 1968. Flowering cycles and fruit types of Ficus sycomorus in Israel. New Phytologist 67(3): $745-758$. 
Galil, J. \& Neeman, G. 1977. Pollen transfer and pollination in the common fig (Ficus carica L.). New Phytologist 79(1): 163-171.

Gibert, C., Chadœuf, J., Vercambre, G., Génard, M. \& Lescourret, F. 2007. Cuticular cracking on nectarine fruit surface: Spatial distribution and development in relation to irrigation and thinning. Journal of the American Society for Horticultural Science 132(5): 583-591.

Gözlekçi, S. 2010. Selection studies on fig (Ficus carica L.) in Antalya province of Turkey. African Journal of Biotechnology 9(46): 7857-7862.

Gözlekçi, S., Erkan, M., Karaşahin, I. \& Şahin, G. 2005. Effect of 1-methylcyclopropene (1-MCP) on fig (Ficus carica cv. Bardakci) storage. Acta Horticulturae 798: 325-330.

Guan, J., Hu, M., Shen, C., Zhou, S., Cheng, Y. \& He, J. 2015. Effects of 1-methylcyclopropene on active composition in fruits. In Processing and Impact on Active Components in Food. Massachusetts: Academic Press. pp. 133-137.

Hernández Méndez, T., Gervasini Rodriguez, C. \& Bernalte García, J. 2001a. Sensory quality of cv. Tiberio breba. Acta Horticulturae 605: 233-235.

Hernández Méndez, T., Lozano Ruiz, M. \& Bernalte García, J. 2001b. Effect of temperature on the shelf-life of fig fruit during refrigerated storage. Acta Horticulturae 605: 229232.

Irfan, P.K., Vanjakshi, V., Prakash, M.K., Ravi, R. \& Kudachikar, V.B. 2013. Calcium chloride extends the keeping quality of fig fruit (Ficus carica L.) during storage and shelflife. Postharvest Biology and Technology 82: 70-75.

Jusoh, N.A.M., Ding, P. \& Choon, S.Y. 2019. Performance of fig (Ficus carica L. cv. Ipoh Blue Giant) fruit stored at various storage temperatures. International Journal of Agriculture, Forestry, and Plantation 8: 9-11.

Kader, A.A. 2002. The commercial storage of fruits, vegetables, and florist and nursery stocks. Agricultural Handbook 66: 53-92.

Kader, A.A. 1986. Biochemical and physiological basis for effects of controlled and modified atmospheres on fruits and vegetables. Food Technology 40(5): 99-104.

King, E.S., Hopfer, H., Haug, M.T., Orsi, J.D., Heymann, H., Crisosto, G.M. \& Crisosto, C.H. 2012. Describing the appearance and flavor profiles of fresh fig (Ficus carica L.) cultivars. Journal of Food Science 77(12): 419-429.

Kong, M., Lampinen, B., Shackel, K. \& Crisosto, C.H. 2013. Fruit skin side cracking and ostiole-end splitting shorten postharvest life in fresh figs (Ficus carica L.), but are reduced by deficit irrigation. Postharvest Biology and Technology 85: 154-161.

Kramer, P.J. \& Boyer, J.S. 1995. Water Relations of Plants and Soils. Massachusetts: Academic Press.

Marei, N. \& Crane, J.C. 1971. Growth and respiratory response of fig (Ficus carica L. cv. Mission) fruits to ethylene. Plant Physiology 48(3): 249-254.

Marpudi, S.L., Ramachandran, P. \& Srividya, N. 2013. Aloe vera gel coating for post harvest quality maintenance of fresh fig fruits. Research Journal of Pharmaceutical, Biological and Chemical Sciences 4: 878-887.

Mawa, S., Husain, K. \& Jantan, I. 2013. Ficus carica L. (Moraceae): Phytochemistry, traditional uses and biological activities. Evidence-Based Complementary and Alternative Medicine 2013: 974256.

Melgarejo, P. 1996. The Fig (Ficus carica L.) Tree. Polytechnic University of Valencia, Orihuela, Spain.
Mir, N. \& Beaudry, R.M. 2004. Modified atmosphere packaging. The commercial storage of fruits, vegetables, and florist and nursery stocks. Agricultural Handbook 66: 42-53.

Nisperos-Carriedo, M.O., Baldwin, E.A. \& Shaw, P.E. 1991. Development of an edible coating for extending postharvest life of selected fruits and vegetables. Proceedings of Florida State Horticultural Science 104: 122-125.

Ohta, K., Hosoki, T., Matsumoto, K., Ohya, M., Ito, N. \& Inaba, K. 1997. Relationships between fruit cracking and changes of fruit diameter associated with solute flow to fruit in cherry tomatoes. Journal of the Japanese Society for Horticultural Science 65(4): 753-759.

Opara, L.U., Studman, C.J. \& Banks, N.H. 1997. Fruit skin splitting and cracking. Horticultural Reviews 19: $217-$ 262.

Paladines, D., Valero, D., Valverde, J.M., Díaz-Mula, H., Serrano, M. \& Martínez-Romero, D. 2014. The addition of rosehip oil improves the beneficial effect of Aloe vera gel on delaying ripening and maintaining postharvest quality of several stonefruit. Postharvest Biology and Technology 92: 23-28.

Pallardy, S.G. 2010. Physiology of Woody Plants. Massachusetts: Academic Press. pp. 87-106.

Paull, R. 1999. Effect of temperature and relative humidity on fresh commodity quality. Postharvest Biology and Technology 15(3): 263-277.

Payasi, A., Mishra, N.N., Chaves, A.L.S. \& Singh, R. 2009. Biochemistry of fruit softening: An overview. Physiology and Molecular Biology of Plants 15(2): 103-113.

Rosianski, Y., Freiman, Z.E., Cochavi, S.M., Yablovitz, Z., Kerem, Z. \& Flaishman, M.A. 2016. Advanced analysis of developmental and ripening characteristics of pollinated common-type fig (Ficus carica L.). Scientia Horticulturae 198: 98-106.

Sams, C.E., Conway, W.S., Abbott, J.A., Lewis, R.J. \& BenShalom, N. 1993. Firmness and decay of apples following postharvest pressure infiltration of calcium and heat treatment. Journal of the American Society for Horticultural Science 118(5): 623-627.

Shackel, K.A., Ahmadi, H., Biasi, W., Buchner, R., Goldhamer, D., Gurusinghe, S., Hasey, J., Kester, D., Krueger, B., Lampinen, B., McGourty, G., Micke, W., Mitcham, E., Olson, B., Pelletrau, K., Philips, H., Ramos, D., Schwankl, L., Sibbett, S., Snyder, R., Southwick, S., Stevenson, M., Thorpe, M., Weinbaum, S. \& Yeager, J. 1997. Plant water status as an index of irrigation need in deciduous fruit trees. HortTechnology 7(1): 23-29.

Shahidah, M.N. \& Ding, P. 2020. Trends and advances in edible biopolymer coating for tropical fruit: A review. Food Research International (In press).

Sisler, E.C. \& Blankenship, S.M. 1996. Methods of Counteracting an Ethylene Response in Plants. Washington, DC: U.S. Patent and Trademark Office.

Solomon, A., Golubowicz, S., Yablowicz, Z., Grossman, S., Bergman, M., Gottlieb, H.E., Altman, A., Kerem, Z. \& Flaishman, M.A. 2006. Antioxidant activities and anthocyanin content of fresh fruits of common fig (Ficus carica L.). Journal of Agricultural and Food Chemistry 54(20): 7717-7723.

Sozzi, G.O., Abraján-Villaseñor, M.A., Trinchero, G.D. \& Fraschina, A.A. 2005. Postharvest response of 'Brown Turkey' figs (Ficus carica L.) to the inhibition of ethylene perception. Journal of the Science of Food and Agriculture 85(14): 2503-2508. 
Stover, E., Aradhya, M., Ferguson, L. \& Crisosto, C.H. 2007. The fig: Overview of an ancient fruit. HortScience 42(5): 1083-1087.

Teixeira, A.R.N. \& Ferreira, R.M.B. 2003. Ripening of Fruit Encyclopedia of Food Sciences and Nutrition. 2nd edition. Massachusetts: Academic Press. pp. 5006-5014.

Thompson, A.K. 2010. Modified atmosphere packaging. In Controlled Atmosphere Storage of Fruits and Vegetables. 2nd ed. Wallingford, England: CAB International. pp. 81115 .

Veberic, R., Colaric, M. \& Stampar, F. 2008. Phenolic acids and flavonoids of fig fruit (Ficus carica L.) in the Northern Mediterranean region. Food Chemistry 106(1): 153-157.

Verkerke, W. 1989. Structure and function of the fig. Experientia 45(7): 612-622.

Villalobos, M.D.C., Serradilla, M.J., Martín, A., HernándezLeón, A., Ruíz-Moyano, S. \& de Guía Córdoba, M. 2017. Characterization of microbial population of breba and main crops (Ficus carica) during cold storage: Influence of passive modified atmospheres (MAP) and antimicrobial extract application. Food Microbiology 63: 35-46.

Villalobos, M.D.C., Serradilla, M.J., Ruiz-Moyano, S., Martín, A., López-Corrales, M. \& Córdoba, M.G. 2016 a. Postharvest application of 1-methylcyclopropene (1-MCP) for preservation of 'Albacor' figs (Ficus carica L.). Acta Horticulturae 1194: 853-860.

Villalobos, M.D.C., Serradilla, M.J., Martín, A., RuizMoyano, S., Pereira, C. \& de Guía Córdoba, M. 2016b. Synergism of defatted soybean meal extract and modified atmosphere packaging to preserve the quality of figs (Ficus carica L.). Postharvest Biology and Technology 111: 264-273.
Villalobos, M.D.C., Serradilla, M.J., Martín, A., RuizMoyano, S., Pereira, C. \& de Guía Córdoba, M. 2014. Use of equilibrium modified atmosphere packaging for preservation of 'San Antonio' and 'Banane' breba crops (Ficus carica L.). Postharvest Biology and Technology 98: 14-22.

Wang, H.J. \& Murphy, P.A. 1994. Isoflavone content in commercial soybean foods. Journal of Agricultural and Food Chemistry 42(8): 1666-1673.

Wills, R.B.H., McGlasson, W.B., Graham, D. \& Joyce, D.C. 2007. Postharvest: An Introduction to the Physiology and Handling of Fruit, Vegetables and Ornamentals. 5th ed. Wallingford, England: CAB International.

Nur Athirah Mat Jusoh, Phebe Ding* \& Choon Sea Yeat Department of Crop Science

Faculty of Agriculture

Universiti Putra Malaysia

43400 UPM Serdang, Selangor Darul Ehsan

Malaysia

Phebe Ding*

Faculty of Agriculture and Food Sciences

Universiti Putra Malaysia Bintulu Sarawak Campus

P.O Box 396, Nyabau Road

97008 Bintulu, Sarawak

Malaysia

*Corresponding author; email: phebe@upm.edu.my

Received: 21 January 2019

Accepted: 29 November 2019 